\title{
FACTORS ASSOCIATED WITH BIRTH PREPAREDNESS IN WONOGIRI, CENTRAL JAVA
}

\author{
Hafari Fajria Nuril Ummah'), Eti Poncorini Pamungkasari²), \\ Rita Benya Adriani3)
}

\author{
1)Masters Program on Public Health, Universitas Sebelas Maret \\ ${ }^{2)}$ Department of Public Health, Faculty of Medicine, Universitas Sebelas Maret \\ 3)Department of Occupational Therapy, School of Health Polytechnics Surakarta
}

\begin{abstract}
Background: Making a birth plan before and during pregnancy has shown to facilitate a feeling of self-control and autonomy for pregnant women which inturn have shown a positive impact on pregnancy and birth outcomes. This study aimed to analyze factors associated with birth preparedness in Wonogiri, Central Java.

Subjects and Method: A cross-sectional study was conducted in Wonogiri, Central Java, from April to May 2018. A sample of 200 pregnant women was selected by cluster sampling. The dependent variable was birth preparedness. The independent variables were maternal knowledge on birth signs, maternal knowledge on birth delivery risk factor, parity, family income, husband support, and health personnel support. The data were collected by questionnaire and analyzed by a multiple linear regression.

Results: Birth preparedness was positively associated with multiparity $(b=0.57$; $95 \% \mathrm{CI}=0.20$ to $3.28 ; \mathrm{p}=0.027)$, high income $(\mathrm{b}=0.58 ; 95 \% \mathrm{CI}=1.24$ to 4.36 ; $\mathrm{p}<0.001)$, good knowledge on birth sign $(b=0.77 ; 95 \% \mathrm{CI}=1.12$ to 2.20; $\mathrm{p}<0.001)$, good knowledge on birth delivery risk factor $(\mathrm{b}=0.76 ; 95 \% \mathrm{CI}=0.66$ to $3.35 ; \mathrm{p}=0.004)$, husband support $(\mathrm{b}=0.67 ; 95 \% \mathrm{CI}=0.09$ to $0.28 ; \mathrm{p}<0.001)$, and health personnel support $(b=0.74 ; 95 \% \mathrm{CI}=1.87$ to $4.38 ; \mathrm{p}<0.001)$.

Conclusion: Birth preparedness is positively associated with multiparity, high income, good knowledge on birth sign, good knowledge on birth delivery risk factor, husband support, and health personnel support.
\end{abstract}

Keywords: birth preparedness, knowledge, husband support, health personnel support

\section{Correspondence:}

Hafari Fajria Nuril Ummah. Masters Program on Public Health, Universitas Sebelas Maret. Jl. Ir. Sutami No. 36A, Surakarta 57126, Central Java.

Email: mbakfari93@gmail.com. Mobile:+6285712211401

The 4th International Conference on Public Health

Best Western Premier Hotel, Solo, Indonesia, August 29-30, 2018 | 222 https://doi.org/10.26911/theicph.2018.03.53 